\title{
Rasionalitas Penggunaan Obat Pada Kasus Diare Balita Pasien BPJS Rawat Jalan RSUD Praya
}

\author{
Yayan Hardiansah $^{1)}$, Baiq Ika Arianti ${ }^{2 *}$, Lalu Jufriadi ${ }^{2)}$, Vera Yulandasari ${ }^{3)}$ \\ Email: baiqikaarianti@outlook.co.id \\ 1) Prodi Ners Universitas Qamarul Huda Badaruddin Bagu \\ 2) Prodi Farmasi Universitas Qamarul Huda Badaruddin Bagu \\ 3) Prodi Keperawatan Universitas Qamarul Huda Badaruddin Bagu
}

\begin{abstract}
ABSTRAK
Pelayanan kesehatan yang bermutu adalah pelayanan kesehatan yang dapat memuaskan pemakai jasa pelayanan sesuai dengan tingkat kepuasan rata-rata penduduk serta penyelenggaraannya sesuai dengan kode etik dan standar pelayana yang telah ditetapkan. Penelitian ini bertujuan untuk mengetahui gambaran sejauh mana tingkat rasionalitas penggunaan obat pada kasus diare akut balita pasien BPJS Rawat Jalan RSUD Praya periode Januari-Juni 2015. Metode yang digunakan dalam penelitian ini adalah metode deskriptif analitik, populasi dan sampel dalam penelitian ini adalah jumlah diare akut balita umur 0-5 tahun pasien BPJS Rawat Jalan periode januari-juni 2015 sejumlah 47 kasus. Dari data tersebut diteliti berdasarkan tepat indikasi, tepat obat dan tepat dosis. Data hasil penelitian yang diperoleh dari masing-masing unsur dianalisis secara deskriptif. Hasil yang diperoleh dari penelitian ini yaitu penggunaan obat pada kasus diare akut balita umur 0-5 tahun pasien BPJS Rawat Jalan periode Januari-Juni 2015 sudah rasional dengan melihat persentase yang memenuhi kriteria tepat indikasi $100 \%$, tepat obat $100 \%$ dan tepat dosis $87 \%$.
\end{abstract}

Kata kunci: Rasionalitas Penggunaan Obat, Pasien, Diare Balita, BPJS, Rawat Jalan.

\begin{abstract}
Quality health services are health services that can satisfy service users in accordance with the level of satisfaction of the average population and its implementation in accordance with codes of ethics and standards that have been set pelayana. This study aims to find out the description of the extent to which the rationality of drug use in cases of acute diarrhea toddlers BPJS patient Outpatient RSUD Praya period January-June 2015. The method used in this study is analytical descriptive method, population and sample in this study is the number of acute diarrhea toddlers 0-5 years old patients BPJS Outpatient period januari-june 2015 a number of 47 cases. From these data were examined based on precise indication, precise drug and exact dose. The data of the research obtained from each element are analyzed descriptively. The results obtained from this study is the use of drugs in cases of acute diarrhea aged 0-5 years patients BPJS Outpatient period January-June 2015 was rational by looking at the percentage that meet the criteria precisely $100 \%$ indication, $100 \%$ accurate drug and appropriate dose $87 \%$.
\end{abstract}

Keywords: Rationality of Drug Use, Patient, Toddler Diarrhea, BPJS, Outpatient

\section{A. LATAR BELAKANG}

Kesehatan merupakan hak asasi manusia dan setiap orang berhak mendapatkan pelayanan kesehatan yang optimal sesuai dengan kebutuhan. Hal ini diatur dalam UndangUndang Dasar Negara Republik Indonesia Tahun 1945 Pasal 28-H, Undang- Undang Nomor 40
Tahun 2004 tentang Sistem Jaminan Sosial Nasional (SJSN) dan Undang- Undang Nomor 36 Tahun 2009 tentang Kesehatan. Karena itu setiap individu, keluarga dan masyarakat berhak memperoleh perlindungan terhadap kesehatannya, dan Negara bertanggung jawab agar terpenuhi hak sehat bagi penduduknya 
termasuk bagi masyarakat miskin dan tidak mampu.

Penggunaan antibiotik tentu diharapkan mempunyai dampak positif akan tetapi penggunaan antibiotik yang tidak rasional akan menimbulkan dampak negatif. Dampak negatif dari penggunaan antibiotik yang tidak rasional antara lain muncul dan berkembangnya bakteri yang resisten terhadap antibiotik, terjadinya toksisitas atau efek samping obat, sehingga perawatan penderita menjadi lebih lama, biaya pengobatan menjadi lebih mahal, dan akhirnya menurunnya kualitas pelayanan kesehatan (Thielma dan Gurrant, 2004)

Pasien yang diare biasanya banyak kehilangan cairan tubuh (dehidrasi), Oralit merupakan cairan elektrolit-glukosa yang sangat esensial dalam pencegahan dan rehidrasi penderita dengan dehidrasi ringan-sedang. Badan Kesehatan Dunia (WHO) merekomendasikan Oralit larutan yang mengandung $90 \mathrm{mmol} / \mathrm{litre}$ natrium dan 111 $\mathrm{mmol} /$ liter glucosa jenis sediaan ini telah terbukti digunakan secara efektif di negara-negara sedang berkembang dimana diare umumnya diebabkan oleh bakteri (Martindale, 1989)

Diare adalah buang air besar yang tidak normal dan cair, dengan frekwensi lebih banyak dari biasanya (Neonatus $>4$ kali dan anak-anak $>3$ kali dalam sehari) (Soeparto, dkk 1997).

Diare perlu mendapat perhatian khusus dari kalangan praktisi medis, karena bila kasus diare tidak dilakukan manajemen terapi yang baik dan benar akan dapat menimbulkan kegawatan yang tidak diinginkan. Kasus diare yang terjadi disemua rumah sakit baik rumah sakit umum maupun rumah sakit swasta tingkat kabuaten/ kota, penyakit diare ini perlu mendapatkan penanganan yang serius terutama pada balita, sering terjadi diare pada anak akan berakibat buruk pada status gizi, kesehatan dan pertumbuhan. Penyakit diare juga perlu untuk mendapatkan terapi pengobatan yang tepat dan rasional untuk menunjang cepatnya penyembuhan pada kasus diare anak.

\section{B. METODE PENELITIAN}

\section{Desain Penelitian}

Penelitian ini menggunakan metode deskriftif analitik yakni suatu penelitian yang bertujuan untuk memberikan gambaran tentang realitas pada obyek yang diteliti secara obyektif. (Nawawi, 1995)

Data dikumpulkan secara retrospektif yakni dengan melihat data-data yang sudah ada untuk diteliti.

\section{Populasi dan Sampel Penelitian}

Populasi yang digunakan dalam penelitian ini adalah jumlah pasien diare akut balita umur 0-5 tahun BPJS Rawat Jalan di RSUD Praya periode Januari - Juni 2015.

Sedangkan sampel yang digunakan dalam penelitian ini adalah sampel jenuh atau total sampling artinya jumlah sampel sama dengan jumlah poulasi. Dengan mengambil kriteria inklusi diare akut pada balita umur (0-5 th ) yang tidak mempunyai penyakit penyerta pasien BPJS Rawat Jalan di RSUD Praya periode januari juni 2015.

Kriteria inklusi dalam pengambilan sampel penelitian ini adalah sebagai berikut 1) anak dengan diagnosa Diare akut tanpa penyakit penyulit/penyerta, 2) usia 0-5 tahun, 3) pasien BPJS Rawat Jalan di RSUD Praya periode januari-juni 2015. Adapun kriteria ekslusi dalam pengambilan sampel penelitian ini sebagai berikut 1) anak dengan diagnose diare mempunyai penyakit Penyulit/Penyerta dan komplikasi, 2) tidak termasuk dalam golongan Usia 0-5 tahun, 3) tidak temasuk pasien BPJS Rawat Jalan di RSUD Praya periode januari-juni 2015.

Teknik pengambilan sampel dalam penelitian ini dengan menggunakan sampel jenuh (total sampling), yaitu besar sampel sama dengan jumlah populasi. (Saryono, 2008). Besar sampel dalam penelitian ini adalah sebanyak 47 resep.

\section{Variabel Penelitian}

Variabel independen yang digunakan dalam penelitian ini adalah penggunaan Antibiotik, Zinc dan oralit pada kasus diare balita yang 
mencakup tepat indikasi, tepatp obat dan tepat dosis.

Variabel dependent yang digunakan dalam penelitian ini adalah rasionalitas penggunaan obat pada kasus diare balita pasien BPJS Rawat Jalan RSUD.

\section{Waktu dan Lokasi Penelitian}

Penelitian ini dilakukan pada SeptemberDesember 2015 dan dilaksanakan di Rawat Jalan RSUD Praya.

\section{Metode pengumpulan dan pengolahan data}

Data Primer pada penelitian ini adalah jumlah diare akut pada balita umur 1-2 tahun pasien BPJS Rawat Jalan di RSUD Praya periode januari-juni 2015 sedangkan data sekundernya adalah 1) berupa formulir indikator peresepan balita umur 1-2 tahun pasien BPJS rawat jalan RSUD Praya periode januari-juni 2015, 2) status/ catatan rekam medis pasien balita umur 1-2 tahun tahun pasien BPJS rawat jalan RSUD Praya dari bulan januari-juni 2015.

Pengolahan data dilakukan dengan manual dan ditabulasi serta disajikan dalan tabel frekuensi sederhana untuk direpresentasikan.

\section{HASIL DAN PEMBAHASAN}

\section{Jumlah Kasus Diare}

Jumlah kasus diare akut pada balita umur (05 tahun) pasien BPJS Rawat Jalan RSUD praya periode Januari - juni 2015 sebanyak 47 orang.

Tabel 1.Jumlah kasus diare akut balita umur (0-5 tahun) BPJS rawat jalan

\begin{tabular}{|c|c|c|}
\hline No. & Bulan & Jumlah pasien \\
\hline 1 & Januari & 9 \\
\hline 2 & Pebruari & 5 \\
\hline 3 & Maret & 8 \\
\hline 4 & April & 10 \\
\hline 5 & Mei & 7 \\
\hline 6 & Juni & 8 \\
\hline \multicolumn{2}{|c|}{ Total } & 47 kasus \\
\hline
\end{tabular}

Jumlah pasien diare akut balita laki-laki dan perempuan umur 0-5 pasien BPJS Rawat Jalan RSUD Praya periode januari-juni 2015.

Jumlah pasien diare akut balita umur 0-5 tahun BPJS Rawat Jalan yaitu perempuan berjumlah 29 orang sedangkan pasien laki-laki yaitu 18 orang yang digambarkan pada grafik diatas.

Jumlah pasien diare akut balita laki-laki dan perempuan berdasarkan rentan umur Pasien BPJS Rawat Jalan RSUD Praya periode januari - juni 2015.

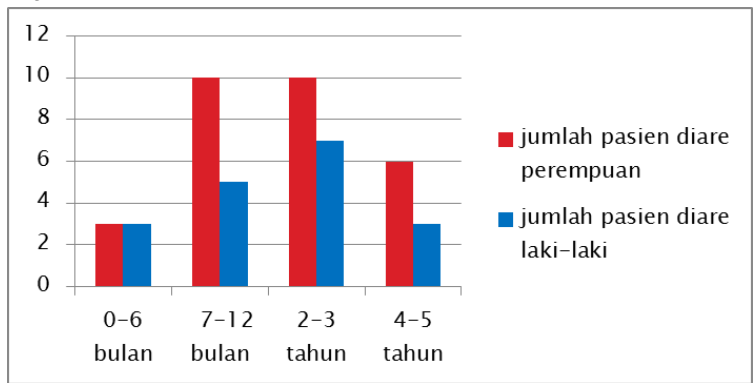

Gambar 1. Grafik Jumlah pasien diare akut balita lakilaki dan perempuan

2. Penggunaan obat diare akut pada balita berdasarkan tepat indikasi, tepat obat dan tepat dosis.

Penggunaan obat diare akut pada balita umur 0-5 tahun pasien BPJS Rawat Jalan RSUD Praya periode januari - juni 2015, berdasarkan tepat indikasi, tepat obat dan tepat dosis dapat dilihat pada Tabel 2, Tabel 3, dan Tabel 4.

Hasil anamnesis didapat informasi pasien mengalami $\mathrm{BAB}$ dengan frekwensi lebih dari $3 \mathrm{x}$ sehari dengan konsistensi tinja yang lebih lembek/ lebih cair dari biasanya/ normal.

Tabel 2. Rasionalitas penggunaan obat berdasarkan tepat indikasi

\begin{tabular}{|c|c|c|}
\hline Kriteria & $\begin{array}{c}\text { Jumlah } \\
\text { (orang) }\end{array}$ & $\begin{array}{c}\text { Persentase } \\
(\%)\end{array}$ \\
\hline Rasional & 47 & 100 \\
\hline Tidak Rasional & 0 & 0 \\
\hline Jumlah & 47 & 100 \\
\hline
\end{tabular}

Tabel 3. Rasionalitas penggunaan obat berdasarkan tepat obat

\begin{tabular}{|c|c|c|}
\hline Kriteria & $\begin{array}{c}\text { Jumlah } \\
\text { (orang) }\end{array}$ & $\begin{array}{c}\text { Persentase } \\
(\%)\end{array}$ \\
\hline Rasional & 47 & 100 \\
\hline Tidak Rasional & 0 & 0 \\
\hline Jumlah & 47 & 100 \\
\hline
\end{tabular}

Penggunaan Obat diare berdasarkan tepat dosis dengan kriteria dosis diberikan sesuai dengan aturan pakai obat dengan mempertimbangkan umur dan berat badan pasien. 
Tabel 4. Rasionalitas penggunaan obat berdasarkan tepat dosis

\begin{tabular}{|c|c|c|}
\hline Kriteria & $\begin{array}{c}\text { Jumlah } \\
\text { (orang) }\end{array}$ & $\begin{array}{c}\text { Persentase } \\
(\%)\end{array}$ \\
\hline Rasional & 41 & 87,23 \\
\hline Tidak Rasional & 6 & 12,76 \\
\hline Jumlah & 47 & 100 \\
\hline
\end{tabular}

\section{Pembahasan}

Diare akut adalah buang air besar lembek/ cair konsistensinya encer, lebih sering dari biasanya disertai berlendir, bau amis, berbusa bahkan dapat berupa air saja yang frekwensinya lebih sering dari biasanya. Diare non spesifik adalah diare yang bukan disebabkan oleh kuman khusus maupun parasit. Penyebab diare akut adalah virus, makanan yang merangsang atau yang tercemar toksin, gangguan pencernaan dan sebagainya.

Penatalaksanaan diare akut telah menetapkan beberapa unsur utama dalam penanggulangan diare akut yaitu Pemberian cairan berupa upaya rehidrasi oral (URO) untuk mencegah maupun mengobati dehidrasi.

Melanjutkan pemberian makanan seperti biasa, terutama ASI, selama diare dan dalam masa penyembuhan. Tidak menggunakan antidiare, sementara antibiotik maupun antimikroba hanya untuk kasus tersangka kolera, disentri atau terbukti giardiasis atau amubiasis. Pemberian petunjuk yang efektif bagi ibu dan anak serta keluarga tentang upaya rehidrasi oral di rumah, tanda-tanda untuk merujuk dan cara mencegah diare di masa yang akan datang. (WHO, 2009)

Dasar pengobatan diare akut adalah rehidrasi dan perbaiki keseimbangan cairan dan elektrolit. Diare dengan dehidrasi berat terdapat tanda-tanda seperti latargis/ tidak sadar, mata cekung, tidak bisa minum atau malas minum, cubitan kulit perut kembali sangat lambat kurang lebih dua detik Rencana Terapi C. Tata laksana balita yang mengalami dehidrasi berat diberikan rehidrasi intravena secara cepat dengan pengawasan yang ketat dan dilanjutkan dengan rehidrasi oral seger setelah balita membaik. Diare dengan dehidrasi ringan/ sedang, terdapat tanda-tanda seperti balita mengalami rewel/ gelisah, mata cekung, minum dengan lahap, haus, cubitan kulit kembali lambat, tata laksana atau pengobatannya yaiu beri balita cairan dan makanan untuk dehidrasi ringan Rencana terapi $\mathrm{B}$, kunjungi ulang dalam waktu 5 hari jika tidak membaik. Diare Tanpa Dehidrasi tidak terdapat cukup tanda-tanda untuk diklasifikasikan sebagai dehidrasi ringan atau berat, Penangananya beri cairan dan makanan untuk menangani diare di rumah rencana terapi A, nasihati ibu kapan kembali segera, kunjungan ulang dalam waktu 5 hari jika tidak membaik. (WHO, 2009 ).

Oralit yang diberikan pada balita yang diare berfungsi mengganti cairan tubuh yang hilang, oralit diberikan berdasarkan tingkat dehidrasi yang dialaminya dengan dosis pada balita tanpa dehidrasi diberikan oralit 10-20 $\mathrm{ml} / \mathrm{kg} \mathrm{BB}$, pada balita dengan dehidrasi ringan/ sedang, diberikan oralit dengan dosis $50 \mathrm{ml} / \mathrm{kg}$ BB. Zinc diberikan pada balita yang diare untuk mengganti nutrisi yang hilang selama diare berlangsung dengan dosis balita umur dibawah 6 bulan diberikan $1 / 2$ tablet sehari dengan cara dilarutkan dengan air dalam sendok atau bisa dicampurkan dengan oralit, sedangkan balita umur 6 bulan ke atas diberikan tablet zink 1 tablet sehari selama 10 hari, zink tetap diberikan selama 10 pada balita meskipun diare sudah berhenti untuk mencegah terjadinya diare 2-3 bulan ke depannya. Balita yang mengalami diare disertai dengan demam/ pebris karna efek dari diarenya diberikan penambahan obat paracetamol sirup dengan dosis $10 \mathrm{ml} / \mathrm{kg} \mathrm{BB} /$ 3x sehari.

Pemberian makan dan minum pada balita yang di diare juga tetap diberikan bila perlu lebih banyak dari biasanya untuk mencegah balita tidak kekurangan gizi dan asupan makanan, balita yang diare lebih banyak diberikan minum dan makanan yang mudah dicerna seperti sup dan kuah sayur agar balita tidak mengalami penurunan berat badan yang derastis selama diare. Balita yang masih minum ASI tetap diberikan lebih sering untuk membantu 
penambahan nutrisi selama diare.

Penelitian ini menggunakan metode Retrosfektif yaitu melihat data-data yang sudah ada untuk diteliti, dengan tujuan untuk mengetahui rasionalitas penggunaan obat pada kasus diare akut balita pasien BPJS Rawat jalan RSUD Praya periode januari- Juni 2015. Objek penelitian ini berupa data/ status rekam medis dan resep obat diare akut balita pasien BPJS Rawat Jalan RSUD Praya periode januari- juni 2015, sejumlah 47 sampel yang diambil menggunakan metode sampel jenuh/ Total sampling sehingga dalam penelitian ini didapat penggunaan obat yang tepat indikasi $100 \%$, tepat obat $100 \%$ dan tepat dosis $87 \%$. Dari data diatas menunjukkan penggunaan obat pada kasus diare akut balita umur 0-5 tahun pasien BPJS Rawat Jalan RSUD Praya periode januari- juni 2015 sudah rasional.

Hal ini dapat dimungkinkan karena pasien yang dilayani adalah pasien BPJS yang sudah ditetapkan buku pedoman tentang Formularium (Fornas) obat program BPJS oleh pemerintah. Tenaga medis / Dokter yang berada dibawah fasilitas pelayanan kesehatan pemerintah wajib menggunakan obat generik, ketentuan ini diatur dalam Peraturan Mentri Kesehatan RI Nomor 085/Menkes/PER/1/1989. Adanya standar pelayanan medis di RSUD Praya yang menjadi pedoman bagi para dokter dalam melaksanakan pengobatan terhadap pasien, khususnya pengobatan terhadap kasus diare di RSUD Praya.

\section{KESIMPULAN}

Berdasarkan penelitian yang dilakukan pada data Rekam Medis dan Resep Obat diare akut balita umur 0-5 tahun pasien BPJS Rawat Jalan RSUD Praya periode januari-juni 2015, dapat ditarik kesimpulan sebagai berikut 1) jumlah kasus diare akut balita umur 0-5 tahun pasien BPJS Rawat Jalan RSUD Praya periode januarijuni 2015 adalah sebanyak 47 kasus, 2) penggunaan obat pada kasus diare akut balita umur 0-5 tahun pasien BPJS Rawat Jalan RSUD Praya berdasarkan tepat Indikasi $100 \%$, 3) penggunaan obat pada kasus diare akut balita umur 0-5 tahun pasien BPJS Rawat Jalan RSUD Praya berdasarkan tepat Obat $100 \%$, 4) penggunaan obat pada kasus diare akut balita umur 0-5 tahun pasien BPJS Rawat Jalan RSUD Praya berdasarkan tepat dosis $87 \%, 5$ ) ketepatan penggunaan obat dengan melihat persentase pemberian obat pada kasus diare akut balita umur 0-5 tahun pasien BPJS Rawat Jalan RSUD Praya yang mencakup pemakaian obat berdasarkan tepat indikasi $100 \%$, tepat obat $100 \%$ dan tepat dosis $87 \%$, sudah rasional.

\section{DAFTAR PUSTAKA}

[1] Anonim. 2002. Profil Standar Pelayanan Medik, RSUD Praya

[2] Anonim. 2014. Profil RSUD Praya, Kabupaten Lombok Tengah.

[3] Anonim. 2009. WHO Buku Saku Pelayanan Kesehatan Anak di Rumah Sakit Rujukan Tingkat Pertama di Kabupaten/ Kota: Jakarta.

[4] Atmojo, SM. 1998. Faktor-faktor yang Mempengaruhi Kejadian Diare Anak, Fakultas UGM: Yogyakarta.

[5] Daldiyono. 1997. Buku ajar diare pegangan bagi mahasiswa, Fakultas Kedokteran: Surabaya.

[6] Mansjoer, Arif.,et al. 1999. Kapita Selekta Kedokteran. Fakultas Kedokteran. UI: Media Aescullapius: Jakarta.

[7] Martindale. 1989. The Complete Drug Reference 35th edition 2. Informatorium Obat Generik Dirjen POM. Depkes RI. Indonesia.

[8] Mboi, Nafsiah. 2013. Buku Saku Badan Penyelenggara Jaminan Sosial Kesehatan. (http://www.itjen.depkes.co.id/Buku Saku BPJS.Pdf). Tanggal (Akses 20 Juli 2015).

[9] Nasirah, Bahaudin. 2010. Implementasi Kebijakan Penggunaan Obat Rasional (POR) di Indonesia, Direktur Penggunaan Obat Rasional, Dirjen Bina Kefarmarmasian dan Alat Kesehatan, Depkes RI: Yogyakarta.

[10] Nasirah, Nawawi, H. 1995. Ilmu Kesehatan Anak, Vol.2 Edisi 15, Penerbitan Buku Kedokteran EGC: Jakarta.

[11] Nursalam. 2007. Konsep dan Penerapan Metodologi Penelitian Ilmu Keperawatan, 
Pedoman Skripsi, Tesis dan Instrumen Penelitian. Buku Kedokteran EGC: Jakarta.

[12] Pitono, S. dkk. 1997. Gastroenterologi Anak. GRAMIK FK Universitas Airlangga: Surabaya.

[13] Saryono. 2008. Metodologi Penelitian Kesehatan. Mitra Cendikia Press: Yogjakarta.

[14] Sastramihardja, H.S. 1997. Pengguaan Obat Yang Rasional di Tempat Pelayanan Kesehatan.

[15] Soemarto. 1994. Pedoman Diagnosis dan Terapi Laboratorium Lab/ UPF Ilmu Kesehatan Anak, Penerbit Universitas Airlangga :Surabaya.

[16] Sugiono. 2008. Statistika Untuk Penelitian. CV. Alfabeta : Bandung.

[17] Sukandar, Yulinah., et al. 2008. ISO Farmakoterapi, Penerbit PT. ISPI: Jakarta

[18] Tjay, Tan Hoan dan Raharja, Kirana. 1997. Obat-Obat Penting Kegunaan dan Efek sampingnya. PT Gramedia : Jakarta. 